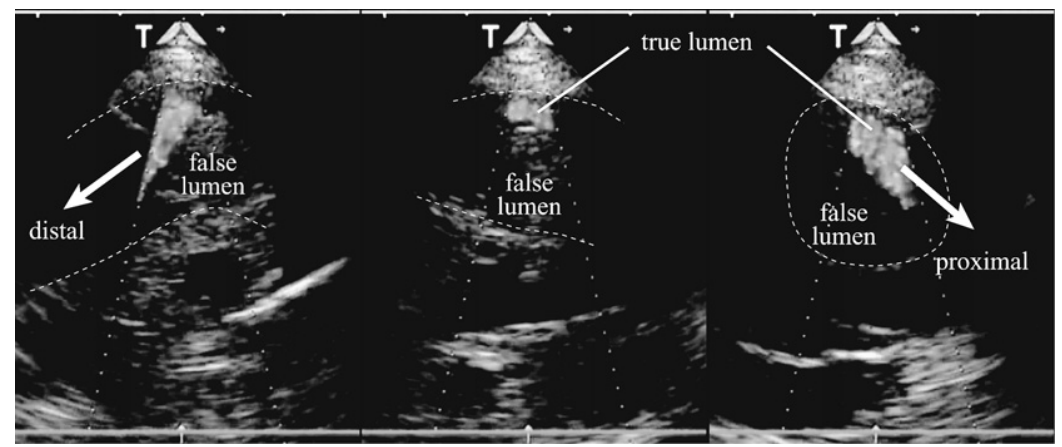

FIGURE 2. Intraoperative transesophageal echocardiogram demonstrating the narrow true lumen of the IA.

presence of reentry, we decided to add left AX-P because the bilateral axillary arteries had been routinely prepared for selective cerebral perfusion at the Hiroshima University Hospital. The addition of FA-P might be another strategy in other institutions.

Because there are unpredictable factors in acute aortic dissection, decisions need to be made stepwise and be based on real-time information at each step. Although our initial assessment was incorrect, TEE and orbital Doppler findings steered the subsequent management toward a good outcome.

Compression of IA can be a mechanism of malperfusion after right AX-P. In acute aortic dissection with many unpre- dictable factors, real-time, on-site information is essential for intraoperative navigation.

\section{References}

1. Pasic M, Schubel J, Bauer M, Yankah C, Kuppe H, Weng YG, et al. Cannulation of the right axillary artery for surgery of acute type A aortic dissection. Eur J Cardiothorac Surg. 2003;24:231-5.

2. Orihashi K, Matsuura Y, Sueda T, Watari M, Okada K, Sugawara Y, et al Aortic arch branches are no longer a blind zone for transesophageal echocardiography: a new eye for aortic surgeons. J Thorac Cardiovasc Surg. 2000; 120:466-72.

3. Orihashi K, Sueda T, Okada K, Imai K. Detection and monitoring of complications associated with femoral or axillary arterial cannulation for surgical repair of aortic dissection. J Cardiothorac Vasc Anesth. 2006;20:20-5.

\title{
Partial left ventricular support implanted through minimal access surgery as a bridge to cardiac transplant
}

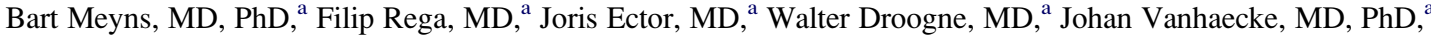 \\ Jan Van Hemelrijck, MD, PhD, ${ }^{\mathrm{a}}$ Bartley Griffith, MD, ${ }^{\mathrm{b}}$ Robert Dowling, MD, ${ }^{\mathrm{c}}$ Mark Zucker, MD, ${ }^{\mathrm{d}}$ and Daniel Burkhoff, MD, PhD, ${ }^{\mathrm{e}}$ \\ Leuven, Belgium, College Park, Md, Louisville, Ky, Newark, NJ and New York, NY
}

The clinical benefits of implantable left ventricular assist devices (LVADs) as a bridge to transplant and for destination therapy have been demonstrated. ${ }^{1-3}$ The low rate of LVAD use is attributed to the invasive nature of the implantation surgery and the relatively high rate of complications. ${ }^{4}$ If

\footnotetext{
From the University Hospital, Leuven, Belgium, ${ }^{\text {a }}$ University of Maryland, College Park, Md, ${ }^{\mathrm{b}}$ University of Louisville, Louisville, Ky, ${ }^{\mathrm{c}}$ Newark Beth Israel Medical Center, Newark, $\mathrm{NJ},{ }^{\mathrm{d}}$ and Columbia University, New York, NY. ${ }^{\mathrm{e}}$

Synergy Micro-Pump (CircuLite, Inc, Hackensack, NJ) was provided by the manufacturer.

Received for publication Dec 30, 2007; accepted for publication Feb 2, 2008.

Address for reprints: Filip Rega, MD, University Hospitals Leuven, Cardiac Surgery, Herestraat 49, 3000 Leuven, Belgium.

J Thorac Cardiovasc Surg 2009;137:243-5

$0022-5223 / \$ 36.00$

Copyright (c) 2009 by The American Association for Thoracic Surgery

doi:10.1016/j.jtcvs.2008.02.010
}

LVADs were used in less critical hemodynamic and clinical states, the flow requirements could be reduced.

The Synergy Micro-Pump (CircuLite, Inc, Hackensack NJ) is approximately the size of a size AA battery, weighs only $25 \mathrm{~g}$, and can pump as much as 2.5 to $3 \mathrm{~L} / \mathrm{min}$. Its small size permits insertion through a right-sided minithoracotomy. The pump is then placed subcutaneously in the pectoral region, similar to a pacemaker. This is the first clinical report describing the Synergy Micro-Pump's implantation procedure, hemodynamic effects, and clinical results.

\section{CLINICAL SUMMARY}

The patient was a 46-year-old man (weight $85 \mathrm{~kg}$, height $184 \mathrm{~cm}$, body surface area $2.01 \mathrm{~m}^{2}$ ) without significant illness in his medical history who had a large anterior myocardial infarction in March 2007. New York Heart Association 


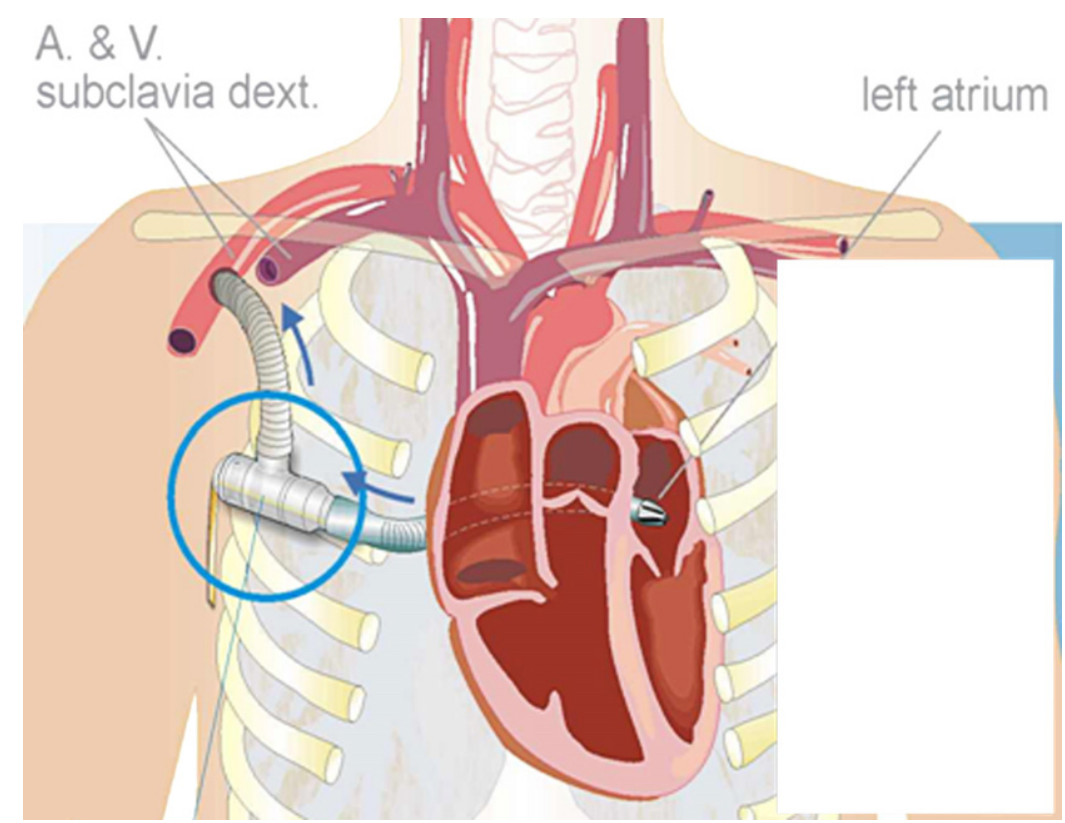

FIGURE 1. Drawing illustrating pump position and direction of pump flow with radiographic correlation in anteroposterior view. A. \& V. subclavia dext., Right subclavian artery (red) and vein (purple).

functional class IV symptoms developed within 2 months (cardiac index $2.2 \mathrm{~L} /\left[\mathrm{min} / \mathrm{m}^{2}\right]$, pulmonary arterial pressure $55 / 24$ $\mathrm{mm} \mathrm{Hg}$, pulmonary capillary wedge pressure $31 \mathrm{~mm} \mathrm{Hg}$, maximum oxygen consumption $8.5 \mathrm{~mL} \mathrm{~kg} / \mathrm{min}$ ). The patient was listed for a heart transplant. His condition continued to deteriorate during the ensuing 6 weeks, however, and he was accepted for investigational study of the Synergy Micro-Pump. This study was conducted in accordance with the Declaration of Helsinki according to a study protocol approved by the Leuven University Ethics Committee and the Belgian Compe- tent Authority. The study protocol was approved by the University Hospitals Leuven Ethical Committee on April 10, 2007.

After informed consent was obtained (June 28, 2007), the patient underwent elective surgery. Hemodynamics after anesthesia included an arterial pressure of $96 / 69 \mathrm{~mm} \mathrm{Hg}$, a cardiac output of $2.5 \mathrm{~L} / \mathrm{min}$, a pulmonary arterial pressure of 55/ $24 \mathrm{~mm} \mathrm{Hg}$, and a pulmonary capillary wedge pressure of 31 $\mathrm{mm} \mathrm{Hg}$. A 4-cm subclavicular incision was made to isolate the right subclavian artery. A small subcutaneous pocket,

TABLE 1. Clinical indices of heart failure and device function

\begin{tabular}{|c|c|c|c|c|c|}
\hline & Preoperative & POD 3 & POD 30 & POD 70 & POD 100 \\
\hline Body weight $(\mathrm{kg})$ & 83 & 85 & 88 & 85 & 88 \\
\hline Heart rate (beats/min) & 96 & 94 & 92 & 85 & 78 \\
\hline New York Heart Association class & IV & IV & III & II & II \\
\hline Arterial blood pressure $(\mathrm{mm} \mathrm{Hg})$ & $85 / 65$ & $94 / 69$ & $97 / 70$ & $92 / 64$ & $11 / 78$ \\
\hline Cardiac index $\left(\mathrm{L} /\left[\mathrm{min} \cdot \mathrm{m}^{2}\right]\right)$ & 1.38 & 2.7 & 1.7 & 2.0 & 2.38 \\
\hline NT pro-BNP (ng/L) & 4698 & - & 4020 & 3129 & 2754 \\
\hline \multicolumn{6}{|l|}{ Renal function } \\
\hline Serum sodium (mmol/L) & 131 & 135 & 137 & 135 & 133 \\
\hline Serum creatinine (mg/dL) & 1.15 & 0.68 & 1.19 & 1.06 & 1.27 \\
\hline Blood urea nitrogen (mg/dL) & 56 & 22 & 47 & 44 & 66 \\
\hline Plasma free hemoglobin* (mg/dL) & $<5$ & 7 & $<5$ & $<5$ & $<5$ \\
\hline Pump speed (rpm) & - & 22,000 & 20,000 & 22,000 & 22,000 \\
\hline Estimated pump flow (L/min) & - & 2.5 & 2 & 2.5 & 2.5 \\
\hline \multicolumn{6}{|l|}{ Medication } \\
\hline Bumetanide (mg) & 2.5 bid & - & - & 1 bid & 2.5 bid \\
\hline Furosemide (mg) & - & $40 \mathrm{qd}$ & $40 \mathrm{qd}$ & - & - \\
\hline Perindopril (mg) & 2 bid & 2 bid & 2 bid & 4 bid & 4 bid \\
\hline Carvedilol (mg) & $3.125 \mathrm{qd}$ & 3.125 bid & 3.125 bid & 6.25 bid & $6.25 \mathrm{bid}$ \\
\hline
\end{tabular}

$P O D$, Postoperative day; $N T$ pro-BNP, N-terminal pronormone brain natriuretic peptide; $b i d$, twice daily; $q d$, daily. *As index of hemolysis. 
similar to a pacemaker pocket, was formed for the pump anterior to the right pectoralis major muscle. An incision was then made in the right fourth intercostal space to gain access to the left atrium through the Waterson groove. The nitinolreinforced silicone inflow cannula was inserted into the left atrium between the insertions of the right upper and lower pulmonary veins. The inflow cannula was tunneled through the second intercostal space to exit the thorax in the area of the subcutaneous pocket. The $8-\mathrm{mm}$ expanded polytetrafluoroethylene outflow graft was anastomosed to the subclavian artery. The electrical wire of the pump was then tunneled to exit the body over the right lower quadrant of the abdomen. Pump speed was set at 22,000 rpm (pump flow approximately $2.5 \mathrm{~L} / \mathrm{min}$ ), the surgical wounds were closed, and the patient was taken to the intensive care unit. The duration of the surgery was approximately 2 hours. Pump position is illustrated in Figure 1.

The patient recovered well from the surgery. Daily therapy was started with warfarin sodium (target international normalized ratio 2.5) and low-dose aspirin $(80 \mathrm{mg})$. The patient is currently ambulatory. He continues to improve his exercise capacity at home, makes visits, and climbs stairs. Table 1 summarizes the evolution of clinical parameters during the first 100 days after the procedure.

The patient had only minor complications. A hematoma developed at the subclavicular wound site on postoperative day 1 but had resolved by postoperative day 4 . Transient swelling developed in the right upper extremity on postoperative 4 but had resolved by postoperative day 7 .

\section{DISCUSSION}

We summarize here the first use of the Synergy MicroPump in a patient as a bridge to transplant. This device pro- vides partial left ventricular support $(2-3 \mathrm{~L} / \mathrm{min})$ and is specifically designed to be implanted in patients who are not as critically ill as the patients now typically receiving full support LVADs. Because of the small size of the device, the surgery was relatively short and significantly less traumatic than with other LVADs. The combination of the patient's intrinsic cardiac output of $3.6 \mathrm{~L} / \mathrm{min}$ with the $2.5 \mathrm{~L} / \mathrm{min}$ provided by the pump summed to a total cardiac output in excess of $6 \mathrm{~L} / \mathrm{min}$, a normal resting value. No significant hemolysis was noted, and there were no serious adverse effects.

There are several unique features of the device. This pump is the smallest implanted assist device ever used as a bridge to transplant. This is the first implanted device with the inflow cannula placed in the left atrium and the outflow cannula connected to the subclavian artery. Because of the unique anatomic position, the procedure was anticipated to be less invasive. As a result, flows of only $2.5 \mathrm{~L} / \mathrm{min}$ were able to produce clinically significant and sufficient acute hemodynamic effects.

\section{References}

1. Miller LW, Pagani FD, Russell SD, John R, Boyle AJ, Aaronson KD, et al. Use of a continuous-flow device in patients awaiting heart transplantation. $N$ Engl J Med. 2007;357:885-96.

2. Rogers JG, Butler J, Lansman SL, Gass A, Portner PM, Pasque MK, et al. Chronic mechanical circulatory support for inotrope-dependent heart failure patients who are not transplant candidates: results of the INTrEPID Trial. J Am Coll Cardiol. 2007;50:741-7.

3. Lietz K, Long JW, Kfoury AG, Slaughter MS, Silver MA, Milano CA, et al. Outcomes of left ventricular assist device implantation as destination therapy in the post-REMATCH era: implications for patient selection. Circulation. 2007; 116:497-505.

4. Deng MC, Edwards LB, Hertz MI, Rowe AW, Keck BM, Kormos R, et al. Mechanical circulatory support device database of the International Society for Heart and Lung Transplantation: third annual report-2005. J Heart Lung Transplant. 2005;24:1182-7.

\title{
A bilobed thoracic outlet mass: Options for resection
}

\author{
Glenn McKay, MD, ${ }^{a}$ Vincent Arlet, MD, ${ }^{\mathrm{b}}$ John A. Kern, MD, ${ }^{\mathrm{a}}$ Christine L. Lau, MD, ${ }^{\mathrm{a}}$ David R. Jones, MD, ${ }^{\mathrm{a}}$ and \\ Benjamin D. Kozower, MD, ${ }^{\text {a }}$ Charlottesville, Va
}

Complete resection of thoracic outlet tumors is challenging because of limited access and close proximity of vital neuro-

\footnotetext{
From the Divisions of Thoracic and Cardiovascular Surgery a and Orthopedic Surgery, ${ }^{\mathrm{b}}$ University of Virginia School of Medicine, Charlottesville, Va. Received for publication Dec 2, 2007; accepted for publication Dec 16, 2007.

Address for reprints: Benjamin D. Kozower, MD, University of Virginia Medical Centre, General Thoracic Surgery, PO Box 800679, Charlottesville, Virginia, VA 22908 (E-mail: bdk8g@virginia.edu).

J Thorac Cardiovasc Surg 2009;137:245-7

$0022-5223 / \$ 36.00$

Copyright (c) 2009 by The American Association for Thoracic Surgery

doi:10.1016/j.jtcvs.2007.12.041
}

vascular structures. We present a hemiclamshell approach with removal of the first rib to facilitate resection of a bilobed mass compressing the right subclavian artery and brachial plexus.

\section{CLINICAL SUMMARY}

A 31-year-old African-American man presented with a 1year history of increasing shoulder pain and right forearm paresthesias. He denied any upper limb weakness, weight loss, fever, or dyspnea. Clinical examination revealed 